\title{
Breast Extraskeletal Osteosarcoma
}

National Cancer Institute

\section{Source}

National Cancer Institute. Breast Extraskeletal Osteosarcoma. NCI Thesaurus. Code C5189.

An osteosarcoma arising from the breast tissue. 